or father. He is followed by the other productive members of the family, i.e. the elder sons and younger brothers. Other older children come next and often the mothers and toddlers are last to be considered. Obviously a programme aimed at the toddler will fail if the type of food it receives is acceptable to the other members of the family, unless there is enough for all.

The animal husbandman is being faced with rising costs all round and a shorter working week. He generally tries to find cheap sources of energy and protein and dietary regimes which will give a considerable concentration of these per unit dry weight. He also wishes to cash in on the most efficient periods of growth and other productions in respect of nutrient utilization. He tries to find labour-saving devices -including changes in dietary pattern - particularly at weekends, but you will hear more about all this from the experts who are with us today.

\title{
Adaptation to the pattern of food intake: some mechanisms and consequences
}

\section{By P. FáBry and T. Braun, Physiology Department, Institute of Human Nutrition, Prague 4, Czechoslovakia}

Man and animals are able to adapt themselves within a relatively wide range to a certain dietary pattern, if at least the indispensable supply of essential nutrients is ensured. It is a sad reflection of nutritional problems in the world that most knowledge on nutritional adaptation was assembled in connexion with starvation and caloric deficiency (Keys, Brožek, Henschel, Mickelsen \& Taylor, 1950; Grande, 1964). It is, however, obvious that from the physiological aspect nutritional adaptation is a much wider problem. Thus for the more fortunate half of mankind, adaptation to an excessive calorie intake is very relevant to the problem of homoeostasis, which is now being studied in more detail (cf. Miller \& Mumford, I966; Strong \& Passmore, i967).

Another aspect is adaptation to a changed composition of the diet. Biochemical and enzymic changes in tissues, as a result of a different proportion of the major dietary constituents, are so marked and typical that they are frequently used by biochemists investigating enzyme adaptations and their mechanisms, as a valuable model.

Fig. I shows a hypothetical scheme of metabolic adaptation to an increase of one of the main nutrients in the diet. The first changes pertain to the gastro-intestinal tract. We know that the activity of digestive enzymes in the pancreas and intestine changes in favour of those which break down the nutrient prevailing in the diet (Grossman, Greengard \& Ivy, r943, r944; Howard \& Yudkin, I963; Ben Abdeljlil $\&$ Desnuelle, 1964; and others). The absorptive function also becomes adapted, obviously as a result of adaptation of systems involved in the active transport of nutrients through the intestine (Long, I953; Lawrie \& Yudkin, I949; and others). 


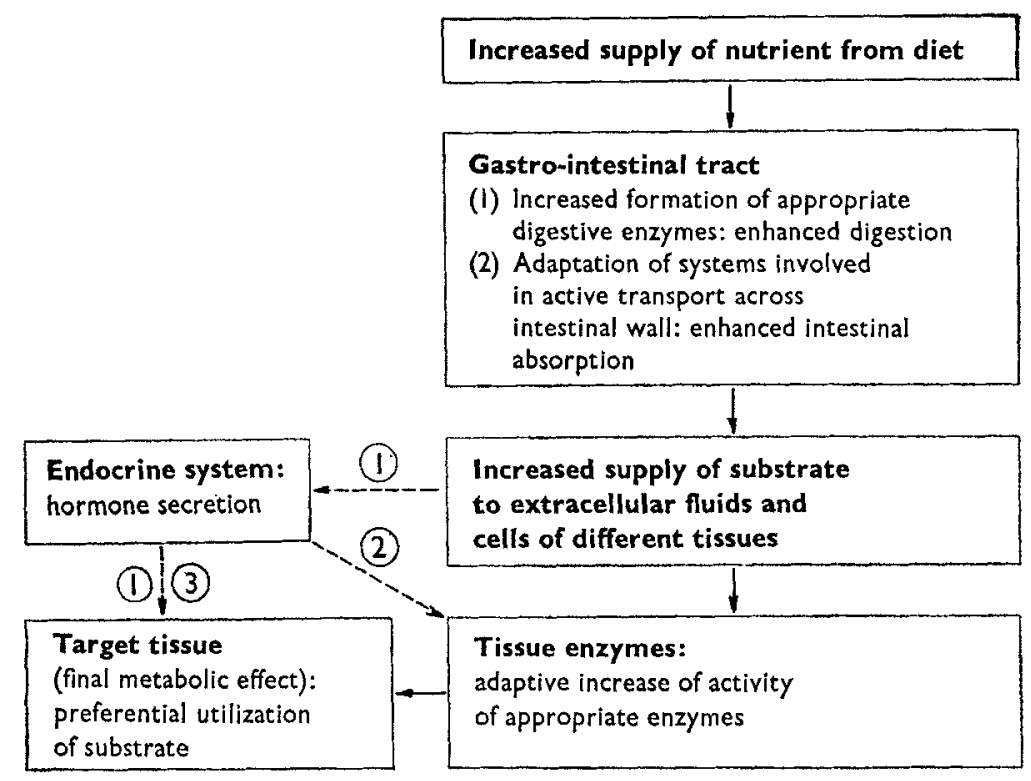

Fig. I. Schematic diagram of metabolic adaptation to the increased supply of a nutrient. (From Fábry, I967b.)

As a response to an increased supply of the predominating substrate to extracellular fluids and to cells of individual tissues, biochemical changes take place in the liver, adipose tissue and elsewhere, the final effect being the preferential utilization of the predominating nutrients and their metabolites (Samuels, 1946; and others). The basis of these changes is probably an induced enzyme synthesis (Knox, Auerbach \& Lin, 1956) though the exact mechanism of such changes has not been elucidated yet and most conclusions are so far based rather on assessment of enzyme activities than on direct evidence of de novo synthesis of enzymes.

Endocrine factors can participate in the metabolic, nutritionally induced adaptation in several ways. (I) The raised blood concentration of the absorbed nutrient can stimulate the output of hormone, such as insulin when a high-carbohydrate diet is taken, and the hormone itself in turn can induce enzymic changes. (z) The hormone may play a 'permissive' role: the stimulus proper for the cell is the diet, i.e. the processed substrate, but a minimum amount of hormone must be present if the adaptive change is to take place. (3) The diet itself may lead to changes in the target tissue and as a result of these changes the tissue may become more sensitive to the hormone. In the last two instances a hormone-dependent metabolic change may take place even without raising either the production or the plasma concentration of the hormone.

From this rather simplified scheme, which does not comprise morphological or histological changes, it is apparent that adaptation to a diet is very complex and involves changes at several levels. I should like to demonstrate now that it is possible to include in an analogous scheme changes which result from adaptation to another dietary factor, the frequency of food intake. 
Work performed in recent years revealed that, in addition to the composition of the diet and its calorie value, the frequency of food intake plays an important part in the regulation of metabolic processes (Tepperman, Brobeck \& Long, i943; Tepperman \& Tepperman, 1958, 1964; Cohn \& Joseph, 1960; Fábry, 1967a, $b$ ). The laboratory rat is basically a 'nibbler' and, if food is readily available, eats more or less continuously. If, however, the access to food is restricted to $\mathrm{I}-2 \mathrm{~h} /$ day or if rats are fed intermittently only for 3 days a week, alternating with $\mathrm{I}-2$ day periods of fasting, the animals soon learn to ingest large amounts of food at a time. This leads to periodic hyperphagia which alternates with relatively longer periods of fasting. The original 'nibbler' thus becomes a 'gorger', though the total food intake may even be reduced, as the rat usually does not fully compensate for the periods of food deprivation. Another experimental approach to the study of the effect of large and infrequent loads of food is the use of force-feeding (gavage) (Cohn \& Joseph, I960).

\section{Adaptation of the gastro-intestinal tract}

According to the scheme in Fig. I, changes in the digestive system should be mentioned first. One of the most striking consequences of periodic hyperphagia in the rat is enlargement of the stomach, in particular of its membranous portion (Holečková \& Fábry, 1959). After a certain time the small intestine also becomes enlarged (Fábry \& Kujalová, 1960) but even before that an increased activity of some enzymes in the intestinal mucosa and an enhanced absorption of glucose and fat are observed (Lojda \& Fábry, 1959; Kujalová \& Fábry, 1960; Fábry, Petrásek, Kujalorá \& Holečková, I962).

\section{Changes in the utilization of nutrients}

A simple calculation shows that a control rat weighing $200 \mathrm{~g}$ consumes its food at a rate of approximately $\mathrm{I}-2 \mathrm{~g} / \mathrm{h}$; the rat trained to intermittent feeding eats, on the other hand, at a rate of $7-\mathrm{I} 5 \mathrm{~g} / \mathrm{h}$. If we consider moreover that intestinal absorption is enhanced (in glucose the increase is about $30 \%$ ), it is obvious that the amount of nutrients which must be processed by tissues per unit of time is enormously increased during the absorptive period. This periodically increased concentration of utilizable substrate is probably the very stimulus which leads to adaptive changes of systems involved in dissimilation, interconversion and oxidation of nutrients and their deposition in reserves. Using Tepperman's (1964) term, we may speak of a 'working hypertrophy' of enzymes.

Since carbohydrates predominate in the normal diet of man and the laboratory rat, it may be expected that, following changes in the pattern of feeding, changes in carbohydrate metabolism will be most marked. An increased activity of several enzymes which catalyse various steps of glucose metabolism was actually found in tissues of animals fed intermittently, beginning with hexokinase (Petrásek, 1959) and ending with enzymes involved in the synthesis of fatty acids from carbohydrate precursors ('Tepperman \& Tepperman, I964; Leveille \& Hanson, I966). Functional changes have been found to be in keeping with the revealed enzyme activities. Rats fed intermittently form more glycogen and fat from ingested carbohydrates 
and have a greater overall glucose tolerance after oral or parenteral glucose administration than controls fed ad lib. (cf. Fábry, I967a,b).

After several weeks of periodic hyperphagia, there is an increase of body fat in most experiments in which an equicaloric food supply is ensured. The mechanism of enhanced lipogenesis will be discussed later.

The increase of body fat in rats force-fed and periodically fed is usually at the expense of total body proteins. Cohn, Joseph, Bell \& Oler ( 1963 ) and Cohn, Joseph, Bell \& Frigerio (1964) found that rats force-fed excrete more urea nitrogen and also have a raised activity of arginine synthetase in the liver. It may be postulated that as a response to periodic loads of a substrate mixture an increased protein turnover and an increased shunting of amino groups in the Krebs urea cycle take place. The deaminated remnants of amino acids can then be used as a source of energy or as material for synthesis of non-nitrogenous body constituents, including fat. This concept is supported by Cohn's findings that forced feeding leads to an increase of body fat even on high-protein diets which contain as much as $67 \%$ protein (Cohn et al. ${ }_{1963}$ ).

The shift of body composition in favour of fat implies a higher calorie retention. In keeping with this, Kekwick \& Pawan (1966) found in force-fed mice a greater positive energy and carbon balance as compared with pair-fed mice consuming the ration ad lib. So far it has not been revealed, however, which component of the energy metabolism is responsible for the higher retention of calories under these conditions or what is the exact mechanism involved.

\section{Adaptive hyperlipogenesis and its mechanism}

As mentioned before, the most striking metabolic consequence of periodic hyperphagia is the accentuation of lipogenetic processes, a phenomenon described by Tepperman \& 'Tepperman (1964, 1965), as 'adaptive hyperlipogenesis'. Several workers have shown that, especially in adipose tissue of periodically fed rats, the formation of fatty acids from acetate and other carbohydrate precursors is greatly enhanced and that the activity of numerous enzymes involved in these processes is increased (cf. Hollifield \& Parson, I962; Stevenson, Feleki, Szlavko \& Beaton, I 964 ; Leveille \& Hanson, I965, I966). Further results from our laboratory, which $I$ am going to present, indicate that spaced feeding leads to a general increase in synthetic processes in the adipose tissue.

We found that a very consistent change in the adipose tissue of rats and mice periodically fed was a raised RNA content (Table $x$ ) which could be connected with an enhanced protein synthesis in this tissue (Braun, Kazdová, Fábry \& Lojda, I965; Braun, Kazdová \& Fábry, I966). We measured therefore the incorporation of a labelled amino acid into protein of adipose tissue in relation to both the lipogenesis and the glycogen content of the tissue. In these experiments all rats were fasted for $22 \mathrm{~h}$ and subsequently given a weighed amount of food for $2 \mathrm{~h}$. From Table 2 it is apparent that, as compared with values on fasting, the increase in amino acid incorporation was much greater in the animals previously adapted to feeding for $2 \mathrm{~h}$ daily than in controls. Basically the same picture was provided by the gly- 
Table I. RNA content of parametrial adipose tissue of female rats and mice fed ad lib. or adapted for 7-1 5 weeks to feeding for $2 h$ daily (rats) or for 9 weeks to intermittent feeding (mice) (data from Braun, Kazdová Eீ Fábry (1966) and Fábry, Kazdová \& Braun (1966))

\begin{tabular}{|c|c|c|c|c|c|}
\hline \multirow[b]{2}{*}{ Group } & \multirow{2}{*}{$\begin{array}{c}\text { Body-weight } \\
\text { (g) }\end{array}$} & \multirow{2}{*}{$\begin{array}{l}\text { Weight of } \\
\text { fat-body } \\
\text { (g) }\end{array}$} & \multicolumn{2}{|c|}{ RNA content of adipose tissue } & \multirow{2}{*}{$\begin{array}{l}\text { Ratio, } \\
\text { RNA : DNA }\end{array}$} \\
\hline & & & mg/fat-body & $\mathrm{mg} / \mathrm{roo} \mathrm{g}$ fresh wt & \\
\hline $\begin{array}{l}\text { Rats ( } 14 \text { animals): } \\
\text { Fed ad lib. } \\
\text { Fed } 2 \text { h/day }\end{array}$ & $\begin{array}{l}228 \pm 7 \cdot 0 \\
226 \pm 5 \cdot 1\end{array}$ & $\begin{array}{l}5.80 \pm 0.30 \\
5.83 \pm 0.33\end{array}$ & $\begin{array}{l}I \cdot 06 \pm 0.06 \\
I \cdot 36 \pm 0.07^{* * *}\end{array}$ & $\begin{array}{l}18 \cdot 4 \mathrm{x} \pm 0.85 \\
23.25 \pm 0.73^{* * *}\end{array}$ & $\begin{array}{l}1.27 \pm 0.04 \\
1.39 \pm 0.04 *\end{array}$ \\
\hline $\begin{array}{l}\text { Mice ( } 7 \text { animals): } \\
\text { Fed ad lib. } \\
\text { Fed intermittently } \dagger\end{array}$ & $\begin{array}{l}35.1 \pm 0.3 I \\
34.8 \pm 0.30\end{array}$ & $\begin{array}{l}I \cdot 72 \pm 0.26 \\
I \cdot 72 \pm 0.15\end{array}$ & $\begin{array}{l}0.42 \pm 0.04 \\
0.57 \pm 0.04\end{array}$ & $\begin{array}{l}25^{\cdot 6} \pm 2 \cdot 03 \\
34^{\cdot 2} \pm I \cdot 48^{* *}\end{array}$ & $\begin{array}{l}\text { I. } 55 \pm 0.05 \\
\text { I.78 } 10.05 * *\end{array}$ \\
\hline
\end{tabular}

Table 2. Effect of frequency of feeding on glycogen content, on in vitro [ $\left.\mathrm{I}^{-14} \mathrm{C}\right]$ acetate incorporation into fatty acids and on $\mathrm{L}-\left[{ }^{14} \mathrm{C}\right]$ phenylalanine incorporation into protein of rat adipose tissue. Results are expressed as percentage of values obtained when the animal had been fasting for 22 (data from Kazdová, Braun, Fábry $\sigma^{2}$ Poledne, 1966)

(Mean values with their standard errors for groups of five or six rats)

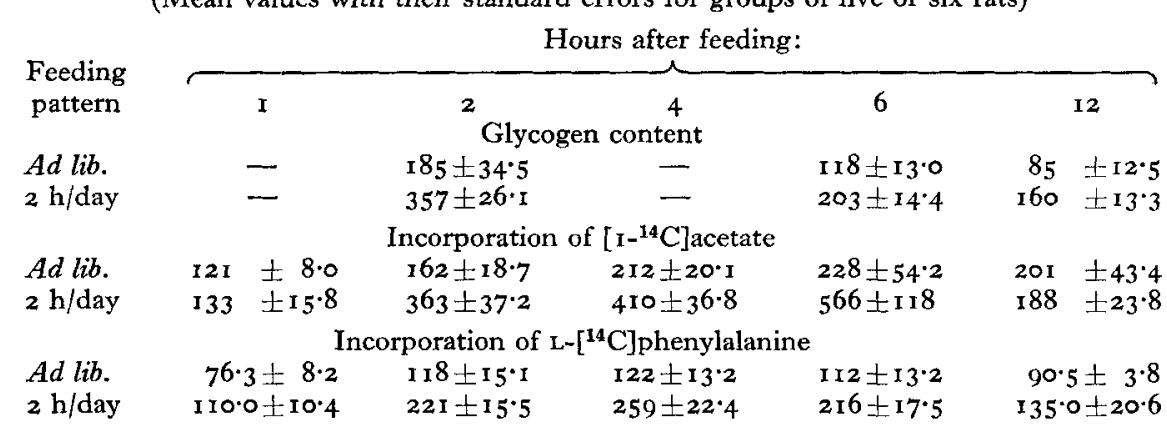

cogen content of adipose tissue and lipogenesis from acetate, the difference being that the peak of lipogenesis was later, i.e. at a time when the glycogen content of tissue was already declining. It is tempting to interpret these findings as a reflection of an enhanced amino acid incorporation into protein for the synthesis de novo of enzymes involved in the fatty acid formation.

The enhanced lipogenesis in the adapted rat does not result in increased filling of individual fat cells with fat and their increase in size, as one would expect. The reason is that in the course of adaptation to spaced feeding a histological transformation of the adipose tissue takes place, the result of which is an increased cellularity of this tissue. In the histological picture of adipose tissue, the fat cells are obviously smaller and more numerous, and the DNA content of the tissue is raised by about $27 \%$ after 7-14 weeks of experimental feeding (Braun et al. 1965). In a recent experiment first one epididymal fat-body was removed and the DNA and fat content were assessed chemically. Then the animals were fed for 30 days, either ad lib. or 
for $2 \mathrm{~h}$ daily. Whereas the average increment of body-weight and epididymal fat was roughly equal in both groups, the increment of DNA was more than twice as large in the periodically fed rats than in the controls (Braun, Kazdová, Fábry \& Vrána, r 967 ). It is probable that the increased cellularity of the adipose tissue, and perhaps also the presence of younger adipocytes, is one of the bases of the higher metabolic activity of the adipose tissue in the adapted rats.

Summarizing the biochemical and histological changes in adipose tissue, we may conclude that, as a result of adaptation to spaced feeding, the overall working capacity of this tissue becomes greatly increased. This may obviously be of primary physiological significance, if we consider the central role of adipose tissue in the formation and storage of energy reserves.

Some of the metabolic changes in the periodically fed rat, especially those revealed in adipose tissue, could be explained by increased insulin secretion. The results in this respect, however, were not unequivocal, when serum hormone levels or insulin-like activity were investigated (cf. Fábry, ig67a,b). On the other hand, we obtained encouraging results when we investigated the sensitivity of animals to exogenous insulin. We found that injections of insulin had a greater hypoglycaemic effect in periodically fed rats than in controls; the difference was probably not being conditioned by a generally increased sensitivity of peripheral tissues to the hormone, but rather by a selectively increased sensitivity of adipose tissue. As is apparent from Table 3 , lipogenesis from $\left[\mathrm{U}_{-}{ }^{14} \mathrm{C}\right]$ glucose in periodically fed rats was about three times greater after insulin injection, than it was in adipose tissue of uninjected controls. On the other hand, the diaphragm of periodically fed rats responded to insulin even less than the diaphragm of controls. It may be assumed that the increased sensitivity of adipose tissue to insulin can play an important part in the mechanism of adaptive hyperlipogenesis (Braun, Vrána \& Fábry, 1967).

Results from several laboratories show that some metabolic effects due to periodic feeding depend on the proportion of carbohydrates in the diet (cf. Fábry, 1967a,b). This seems to be true also with respect to the type of carbohydrate consumed. In a recent experiment we assessed the incorporation of $\left[\mathrm{I}^{-14} \mathrm{C}\right]$ acetate into total lipids and cholesterol of liver slices from rats which had been fed for 6 months either ad lib. or for $2 \mathrm{~h}$ daily. In each group some of the animals received a diet containing $70 \%$ sucrose and the others a diet containing the same proportion of starch. As is apparent from Table 4, sucrose enhanced the incorporation of acetate into both total lipids and cholesterol and accentuated the lipogenetic effect of periodic feeding.

It is worth while paying attention to the fact that periodic feeding increases cholesterol synthesis in the liver (Leveille \& Hanson, i965; Petrásek, Poledne \& Vavrečka, 1966); this may not be unimportant when considered in conjunction with the atherogenic effect of periodic hyperphagia revealed in species other than the rat (cf. Cohn, 1964). 


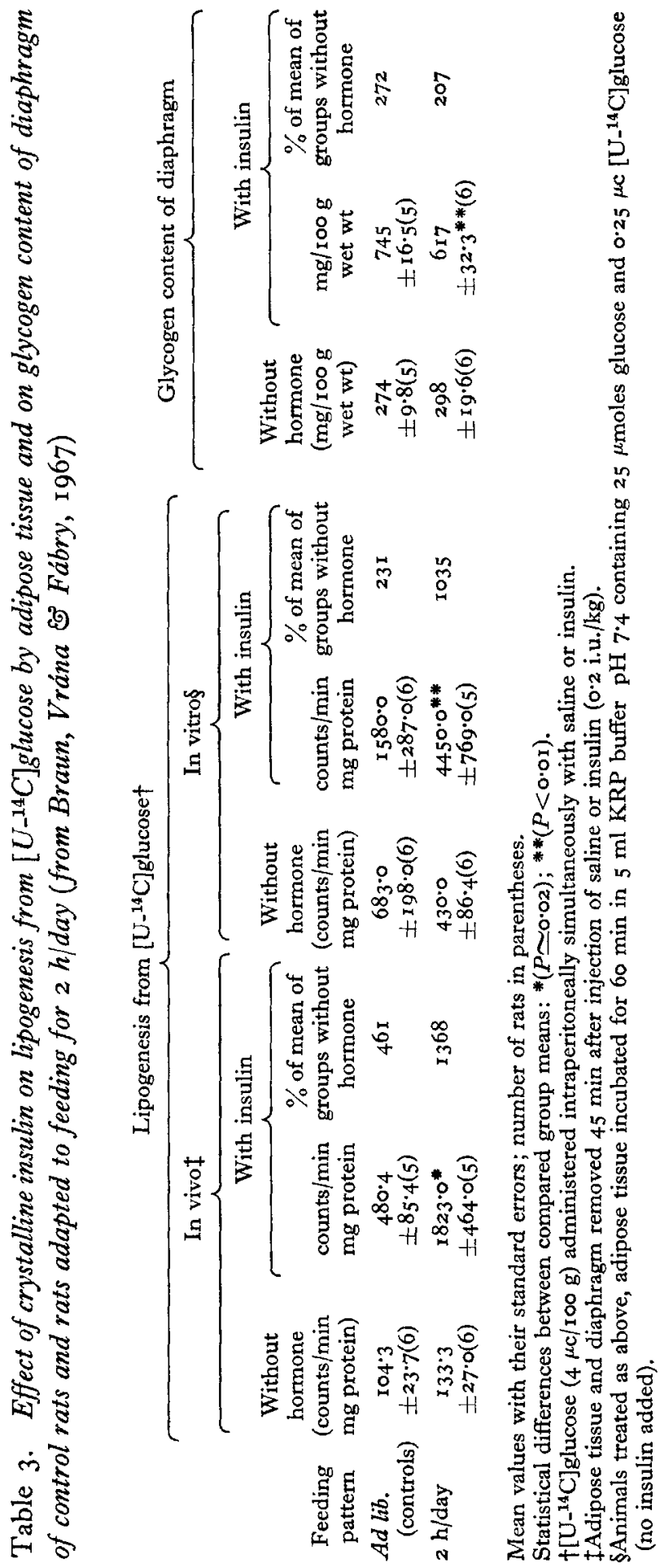


Table 4. Effect of frequency of feeding and diet composition on the in vitro incorporation of $\left[\mathrm{I}^{14} \mathrm{C}\right]$ acetate into total lipids and cholesterol of liver slices in rats after 26 weeks of experimental feeding (unpublished observations of P. Fabry, R. Poledne, L. Kazdová छீ T. Braun)

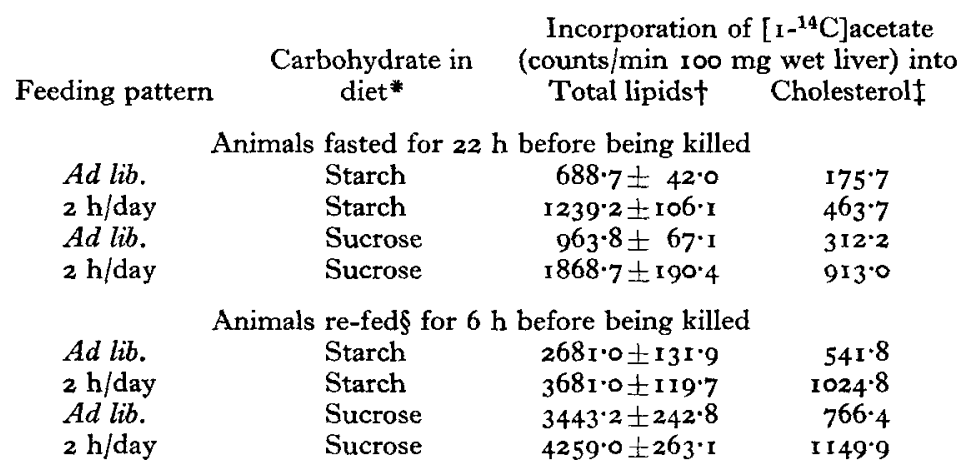

\footnotetext{
*Diets contained $300 \mathrm{~g}$ of a basal mixture and $700 \mathrm{~g}$ starch or sucrose. Both diets provided c. $15 \%$ of calories from protein.

tMean values with their standard errors for six rats each.

$\ddagger$ Pooled samples from six rats each.

$\S$ With a measured amount of food ( $5 \mathrm{~g} / \mathrm{roO} \mathrm{g}$ body-weight) after being fasted for $22 \mathrm{~h}$.
}

\section{Effect of frequency of food intake in man}

It is a problem of the utmost importance whether the frequency of food intake also plays a biologically significant part in man. During the past 3 years we have made several investigations, of some 900 subjects of different ages, which revealed that a pattern of three or fewer larger meals a day, as compared with a more frequent intake of smaller meals (five or more), lead to a tendency towards overweight, and in elderly men also to hypercholesterolaemia and a diminished glucose tolerance (Fábry, Fodor, Hejl, Braun \& Zvolánková, 1964; Fábry, Hejda, Cerny, Osancová \& Pechar, 1966; Fábry, Kazdová \& Braun, r966; Hejda \& Fábry, 1964).

In this paper we have used frequently the term 'adaptation' which is generally associated with a biologically more advantageous situation in relation to the environment. One can, however, hardly consider obesity or hypercholesterolaemia as an advantage in man. In fact the position is somewhat more complicated. In a previous paper Holečková \& Fábry ( 1959 ) pointed out that a pattern in which periods of fasting alternate with overeating resembles that frequently found in wild animals. Under these conditions the enhanced ability to form metabolic reserves is a biologically and ecologically useful adaptation. The same may have applied to our prehistoric ancestor whose dietary pattern - at least at a time when he was mainly a hunter-probably resembled intermittent hyperphagia rather than nibbling.

A busy European or American of today uses a car rather than his natural locomotory apparatus, consumes calories in excess of his physiological need, including some $40-50 \mathrm{~kg}$ sugar per year, and is getting increasingly accustomed to postponing his main meals to the evening. One may ask whether certain adaptive mechanisms 
which developed during long ages of man's struggle for food and existence may not become pathogenetic under the very different conditions of contemporary urban civilization. The metabolic adjustment to spaced feeding may be one of them.

\section{REFERENCES}

Ben Abdeljlil, A. \& Desnuelle, P. (1964). Biochim. biophys, Acta 81, 136.

Braun, T., Kazdová, L. \& Fábry P. (I966). Experientia 22, 16r.

Braun, T., Kazdová, L., Fábry, P. \& Lojda, Z. (1965). Physiologia bohemoslov. I4, 559.

Braun, T., Kazdová, L., Fábry, P. \& Vrána, A. (I967). Cesk. Fysiol. (In the Press.)

Braun, T., Vrána, A. \& Fábry, P. (1967). Experientia. 23, 468.

Cohn, C. (1964). Fedn Proc. Fedn Am. Socs exp. Biol. 23, 76.

Cohn, C. \& Joseph, D. (г 960). Metabolism 9, 492.

Cohn, C., Joseph, D., Bell, L. \& Frigerio, N. A. (1964). Proc. Soc. exp. Biol. Med. 115, 1057.

Cohn, C., Joseph, D., Bell, L. \& Oler, A. (1963). Am. F. Physiol. 205, 71.

Fábry, P. (1967a). In Handbook of Physiology, Alimentary Canal. Vol, 1, Ch. 21. Washington, D.C.: American Physiological Society (In the Press.)

Fábry, P. (1967b). Feeding Pattern and Nutritional Adaptations. Prague: Academia. London: Butterworth. (In the Press.)

Fábry, P., Fodor, J., Hej1, Z., Braun, T. \& Zvolánková, K. (1964), Lancet ii, 614.

Fábry, P., Hejda, S., Cerny, K., Ošancová, K. \& Pechar, J. (1966). Am. F. clin. Nutr. 18, $35^{8}$.

Fábry, P., Kazdová, L. \& Braun, T. (1 966). Cesk. Fysiol. 15, 524.

Fábry, P. \& Kujalová, V. (1960). Acta anat. 43, 264.

Fábry, P., Petrásek, R., Kujalová, V. \& Holečková, E. (1962). Adaptace na zménény príjem potravy. Praha: Státni zdrav. nakladatelství.

Grande, F. (1964). In Handbook of Physiology. Section 4: Adaptation to the Environment, p. 911. Washington, D.C.: American Physiological Society.

Grossman, M. I., Greengard, H. \& Ivy, A. C. (1943). Am. F. Physiol. 138, 676.

Grossman, M. I., Greengard, H. \& Ivy, A. C. (1944). Am. F. Physiol. 141, 38.

Hejda, S. \& Fábry, P. (1964). Nutritio Dieta, 6, 216.

Holečková, E. \& Fábry, P. (1959). Br. Y. Nutr. 13, 260.

Hollifield, G. \& Parson, W. (I962). F. clin. Invest. 4I, 245.

Howard, F. \& Yudkin, J. (1963). Br. F. Nutr. I7, 281.

Kazdová, L., Braun, T., Fábry, P. \& Poledne, R. (1966). Cesk. Fysiol. 15, 522.

Keckwick, A. \& Pawan, G. L. S. (1966). Metabolism 15, 173.

Keys, A., Brožek, J., Henschel, A., Mickelsen, O. \& Taylor, H. L. (1950). The Biology of Human Starvation. Minneapolis: University of Minnesota Press.

Knox, W. E., Auerbach, V. H. \& Lin, E. C. C. (1956). Physiol. Rev. 46, 164.

Kujalová, V. \& Fábry, P. (1960). Physiologia bohemoslov. 9, 35.

Lawrie, N. R. \& Yudkin, J. (I949). Biochem. F. 45, 438.

Leveille, G. A. \& Hanson, R. W. (I965). Can. F. Physiol. Pharmacol, 43, 857.

Leveille, G. A. \& Hanson, R. W. (I966). I. Lipid. Res. 7, 46.

Lojda, Z. \& Fábry, P. (1959). Acta histochem. 8, 289.

Long, C. (I953). Biochem. F. 53, 7.

Miller, D. S. \& Mumford, P. (I966). Proc, Nutr. Soc. 25, 100.

Petrásek, R. (1959). Nature, Lond. 183, 323.

Petrásek, R., Poledne, R. \& Vavrečka, M. (r966). Cesk. Fysiol. I5, 8 I.

Samuels, L. T. (1946). F. Am. diet. Ass. 22, 843 .

Stevenson, J. A. F., Feleki, V., Szlavko, A. \& Beaton, J. R. (1964). Proc. Soc. exp. Biol. Med. x16, г78.

Strong, J. A. \& Passmore, R. A. (1967). Proc. Nutr. Soc. 26, 163.

Tepperman, J. (1964). Physiology for Physicians 2, 5 .

Tepperman, J., Brobeck, J. R. \& Long, C. N. H. (I943). Yale \%. Biol. Med. 15, 855.

Tepperman, J. \& Tepperman, H. M. (1958) Am. F. Physiol. r93, 55.

Tepperman, H. M. \& Tepperman, J. (1964). Fedn Proc. Fedn Am. Socs exp. Biol. 23, 73.

Tepperman, J. \& Tepperman, H. M. (1965). Ann. N.Y. Acad. Sci. 131, 404. 